This item was submitted to Loughborough's Research Repository by the author.

Items in Figshare are protected by copyright, with all rights reserved, unless otherwise indicated.

\title{
Resource Accessibility and Vulnerability in Andhra Pradesh: Caste and Non- Caste Influences
}

PLEASE CITE THE PUBLISHED VERSION

PUBLISHER

(C) Blackwell Publishing Ltd

VERSION

AM (Accepted Manuscript)

LICENCE

CC BY-NC-ND 4.0

\section{REPOSITORY RECORD}

Bosher, Lee S., Edmund Penning-Rowsell, and Sue Tapsell. 2019. "Resource Accessibility and Vulnerability in Andhra Pradesh: Caste and Non-caste Influences". figshare. https://hdl.handle.net/2134/4246. 
This item was submitted to Loughborough's Institutional Repository (https://dspace.lboro.ac.uk/) by the author and is made available under the following Creative Commons Licence conditions.

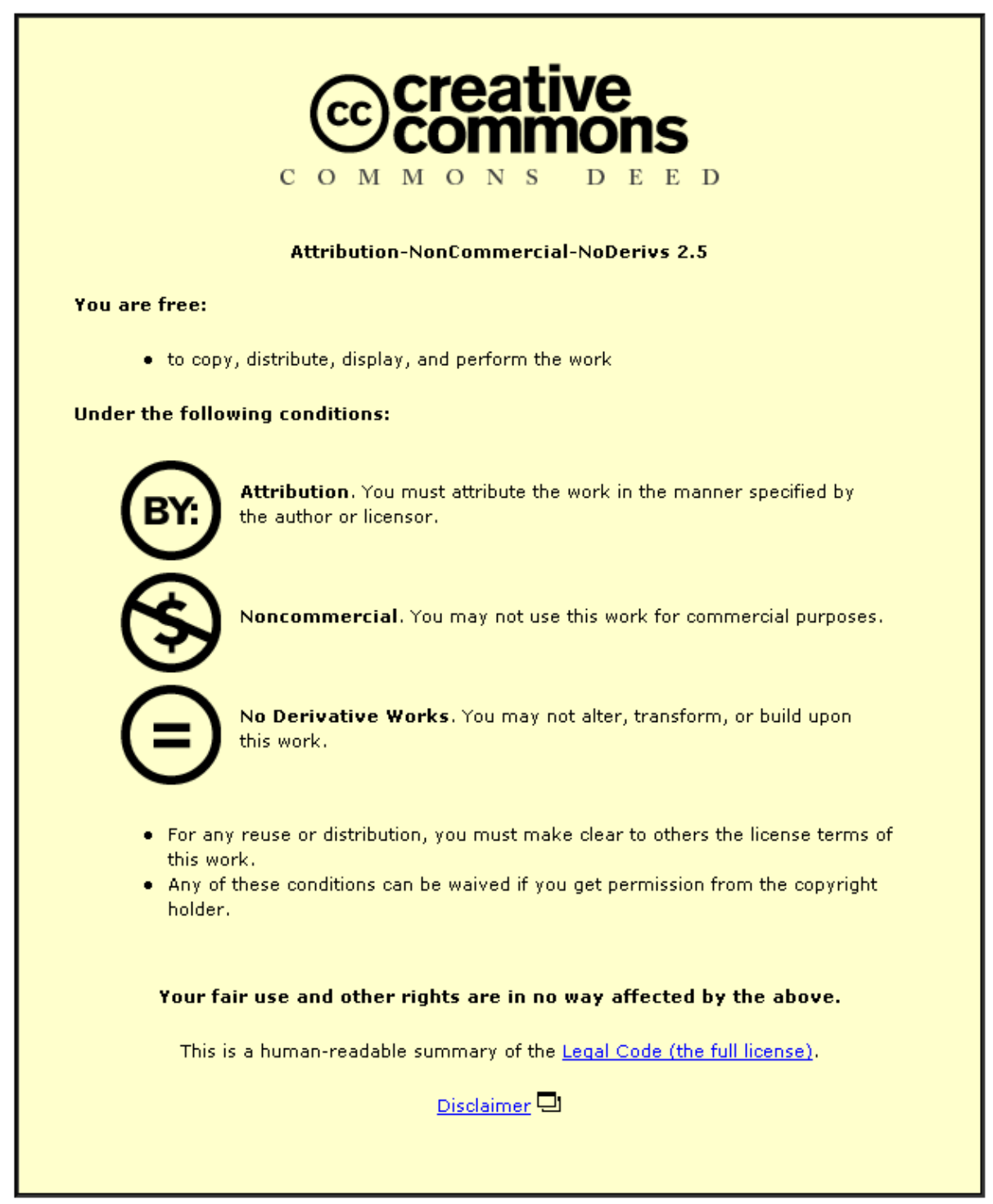

For the full text of this licence, please go to: http://creativecommons.org/licenses/by-nc-nd/2.5/ 


\title{
Resource Accessibility and Vulnerability in Andhra Pradesh: Caste and Non-Caste Influences
}

\section{Lee Bosher, Edmund Penning-Rowsell and Sue Tapsell}

\begin{abstract}
Coastal Andhra Pradesh in southern India is prone to tropical cyclones. Access to key resources can reduce the vulnerability of the local population to both large-scale disasters, such as cyclones, and to the sort of small-scale crises that affect their everyday lives. This article uses primary fieldwork to present a resource accessibility vulnerability index for over 300 respondents. The index indicates that caste is the key factor in determining who has assets, who can access public facilities, who has political connections and who has supportive social networks. The 'lower' castes (which tend to be the poorest) are marginalized to the extent that they lack access to assets, public facilities and opportunities to improve their plight. However, the research also indicates that the poor and powerless lower castes are able to utilize informal social networks to bolster their resilience, typically by women's participation with CBOs and NGOs. Nevertheless it is doubtful whether this extra social capital counterbalances the overall results which show that - despite decades of counteractions by government - caste remains a dominant variable affecting the vulnerability of the people of coastal Andhra Pradesh to the hazards that they face.
\end{abstract}

(First, unnumbered footnote)

The authors are grateful to Middlesex University for financing this research and to Peter Winchester, Sarah Bradshaw and the anonymous reviewers of the journal for their advice. In addition, we would like to thank the individuals and organizations that provided valuable assistance during data collection in Andhra Pradesh. Most importantly, we would like to express our gratitude to all the villagers involved in this study for their time, patience, and generous hospitality. 


\section{INTRODUCTION}

Disaster management has moved away from relief and disaster preparedness, towards a more sustainable approach involving the management of risks (Coles and Buckle, 2004), incorporating strategies for both hazard mitigation and vulnerability reduction. The multi-disciplinary range of modern disaster management strategies is also based on long-term social, economic and environmental adaptations that draw upon assessments of risk, vulnerability and resilience of the individual and the 'community"1 (ibid.).

The pragmatic underpinning of these trends is that when governmental resources are limited or stretched, in-built community level survival strategies such as neighbourly help can augment individual, family and community resilience, and government assistance. However, the ability of an individual, family or community to prepare for, withstand and respond to a hazard or crisis can be constrained by a number of factors such as social status, wealth or poverty, ethnicity, age and gender (Wisner et al., 2004). This article attempts to enhance awareness of the myriad types of human vulnerability - in this case, to cyclone impacts - in the context of rural coastal south India. This is done by assessing 'potential resilience' through a focus upon villagers' access to key socio-economic resources, such as public facilities, assets and social and political networks. An underlying hypothesis is that social capital in the form of these social and political networks might be a substitute for the economic capital that we know enhances resilience (Agarwal, 1990; Davies and Hossain, 1997; Winchester, 1992).

\section{The Context}

Andhra Pradesh is the third largest state in India, covering $275,000 \mathrm{~km}^{2}$, bordering the Bay of Bengal. It is also one of the most cyclone-prone regions of the world.

\footnotetext{
${ }^{1}$ The word 'community' has a number of different meanings which are context specific (Marsh and Buckle, 2001). In the research from which this article originates, 94 per cent of respondents based their concept of community on caste categories, which may (in a single caste village) or may not (in a multi-caste village) equate to the whole village geographically (Bosher, 2005).
} 
Historically, tropical cyclones have been the cause of large-scale losses of human life, livestock, crops, property and infrastructure in Andhra Pradesh, with serious adverse effects on the local and regional economies. Despite the threat of cyclones and floods to the livelihoods and lives of millions of people, many inhabitants remain in the area, through poverty and lack of choices, striving to live in regions dominated by mangrove swamps, brackish rivulets, aquaculture tanks and paddy fields (Reddy et al., 2000).

For the purposes of this study, two regions were selected for research (see Figure 1). East Godavari was chosen because of the relatively recent cyclone disaster that affected the area in November 1996, and the subsequent vulnerability reduction initiatives undertaken by the Andhra Pradesh State Government and local NGOs. These vulnerability reduction initiatives included the construction of community cyclone shelters, storm warning systems, improved evacuation measures, hazard mapping and enhanced community preparedness through education programmes in cyclone-prone areas (Parasuramam and Unnikrishnan, 2000; Reddy et al., 2000). A second region, Nellore, was chosen because of its long history of cyclone disasters, being the most cyclone-affected district in coastal Andhra Pradesh (Reddy et al., 2000).

(Figure 1 about here)

\section{Methodology}

The research reported here was conducted in eight coastal villages in East Godavari district and four coastal villages in Nellore district between February and November 2002 (for more details, see Bosher, 2005, 2007). Emphasis was placed upon the combined use of qualitative and quantitative research methods and the use of triangulation to facilitate rigorous data collection and to allow cross-checking of data during analysis. The respondents were selected using a stratified random sampling technique based on five types of housing ${ }^{2}$ found in the case study villages.

\footnotetext{
${ }^{2}$ Categories of housing used in this study were: Large Pukka (framed concrete housing); Basic Pukka (basic concrete housing, usually constructed with financial assistance of government and/or NGOs); Traditional style tiled housing (typically constructed of mud brick with clay tile roofs); Kutcha houses (basic houses with wood and mud brick walls with thatched roofs); and
} 
Questionnaire surveys ${ }^{3}$ using open and closed questions were undertaken with respondents from the villages, local non-governmental organizations (NGOs) and members of local (Zilla Parishad) and mandal ${ }^{4}$ level government administrations. Detailed cartographic and demographic surveys of the villages were undertaken and sociograms were used (ibid.) to assess individual relationships with social institutions, while key respondents provided qualitative data through semi-structured interviews.

The 342 questionnaires completed in this investigation contributed towards understanding the structure of vulnerability and its interrelations, while the qualitative data obtained from the 308 sociograms and 34 semi-structured interviews provided depth and meaning. An adaptation of the sociogram was developed during the fieldwork to assess individual social networks, with 308 sociograms being completed in relation to an 'everyday' scenario (ibid.). In addition, 294 sociograms were undertaken with the same respondents related to a 'crisis' scenario such as the November 1996 cyclone that affected the East Godavari district, but also 'crisis' events defined by the respondents.

The caste of a respondent was self-defined during the questionnaire surveys; in all cases the respondents named their caste and their 'caste classification' as they perceived it. ${ }^{5}$ In the multi-caste villages it was possible to verify the information provided by the respondents regarding their caste because these villages were typically segmented geographically into 'communities' defined by caste classification.

Kutcha huts (basic mud and bamboo huts with no/minimal load bearing walls and thatched roofs).

${ }^{3}$ Particular attention was paid to the phrasing of questions in the questionnaire in an attempt to avoid ambiguities in the subsequent translation into Telugu. Any remaining ambiguities in the questionnaire were addressed once it was possible to consult a qualified English/Telugu translator in India. The translated version of the questionnaire was checked by an independent translator for grammar and meaning which was an essential consideration to allow for local and colloquial requirements.

${ }^{4}$ A mandal is an administrative section of a District; there are 1104 in Andhra Pradesh. It is sometimes also referred to as Taluk or Taluka.

${ }^{5}$ The authors appreciate that the classification of castes is not without controversy. However, it was deemed that if the classifications cited by the respondents were the accepted nomenclature then it would make 'caste classification' an interesting analytical variable. In addition, the information obtained from questionnaire surveys and interviews made it clear that the 'caste classifications' accepted by the village level respondents were also those used by the local and state level government respondents. 


\section{WHAT CONSTITUTES AND DETERMINES VULNERABILITY?}

Research over the last twenty years has shown that an understanding of the social and economic forces that shape societies should be given the same weight in our assessments of vulnerability as understanding the physical hazard-generating processes (Wisner et al., 2004). Vulnerability is a contested concept but Warmington (1995: 1) provides a useful definition: '[a] condition or set of conditions which adversely affect people's ability to prepare for, withstand and/or respond to a hazard'.

In-built community level survival strategies, such as neighbourly assistance, can provide a level of resilience, but without support from civil society the plight of the rural poor may never improve. This is the philosophy behind contemporary initiatives targeting the most vulnerable members of vulnerable communities (Boyce, 2000; Buckle et al., 2000; DFID, 1999; Hearn Morrow, 1999; World Bank, 1999). But the extent to which an individual or a community has the ability to prepare for, withstand and respond to a hazard or crisis will typically be context-specific. We believe that in coastal rural India, it can be assessed by looking at four key determinants of vulnerability: people's access to assets, to facilities, to political networks and to social networks (details are given in Table 1).

Thus the most vulnerable people and communities typically have few assets and little choice about where they live and how they live (Sen, 1981; Winchester, 1992; World Bank, 1990). Contextually, key assets in coastal Andhra Pradesh are land ownership, income generating equipment and savings. Access to facilities is likely to be strongly influenced by social institutions and networks, which can enable or constrain an individual's ability to access potentially protective public facilities. These facilities can aid resilience by sheltering the vulnerable and by providing them with core public services that supplement their meagre financial resources in the form of a 'social wage'. This determinant has been assessed in terms of access to safe drinking water, medical care, education, community cyclone shelters and/or ownership of a cyclone resistant house.

Inequalities in vulnerability are also influenced by institutions that in some cases have been accused of corruption and nepotism (Kohli, 1990; Kothari, 1986; Narayanasamy et al., 2000; Robbins, 2000). Notwithstanding this, access to key sociopolitical institutions may enable some people or whole communities to obtain vulnerability-reducing resources that are not available to their neighbours. This is a 
complex area, and we have assessed this determinant of vulnerability in terms of access to the organs of the State/District government, the Mandal officials, and the local Panchayat.

The types of social institutions and the strength of social networks may also influence a person's survival strategies, in terms of 'drawing upon communal resources' and 'drawing on social relationships' (Agarwal, 1990). Such relationships may be important in providing vulnerability-reducing resources, particularly when government mechanisms are unavailable or people have been deliberately or otherwise marginalized. This determinant has been assessed in our research in terms of access to social networks with NGOs and with community-based organizations (CBOs), and also with family members within and outside each respondent's village.

\section{THE RESOURCE ACCESSIBILITY VULNERABILITY INDEX (RAVI)}

Interviews were conducted and other sources used to explore the different strengths of these determinants of vulnerability. The original data-set was based on a range of open and closed questions that provided nominal, categorical and interval scale quantitative data, and also detailed textual qualitative data. These data were then reduced to a basic binary level that consisted of 'yes' and 'no' responses to the variables listed in Table 1, providing the foundation for the development of a 'Resource Accessibility Vulnerability Index' (RAVI). This Index was designed during the research to summarize a respondent's or a community's 'potential resilience' or vulnerability (Bosher, 2005). The RAVI was developed in 'the field' due to the lack of a suitable vulnerability index that was appropriate to the context and the subject of the research.

(Table 1 about here)

In the absence of any good basis for weighting the variables differently, this index simply sums scores on each of the twenty variables listed in Table 1. If a respondent had access to all the factors he/she would score a maximum of 20 points on the index, and is therefore likely to be much less vulnerable to the effects of cyclones than those with lower scores: their ability to prepare for, withstand and/or respond to a hazard would be proportionately greater. More complex statistical procedures were 
attempted, to develop a more sophisticated index, but this proved not to add clarity to the analysis (Bosher, 2005).

The mean score on the index is 8.0, and its distribution is usefully near-normal, as indeed are the distributions of its components (Figure 2). To gain an insight into which respondents and communities were potentially the most and the least vulnerable we first examined the lowest and highest quartiles of the RAVI scores across the total sample for both case study areas. The predominant variables and demographic characteristics in the lowest and highest quartiles are summarized in Table 2. Several of the differences here obviously reflect results familiar in literature on socioeconomic vulnerability (Agarwal, 1991, 2001; DFID, 1999; Winchester, 1992; Wisner et al., 2004) in that the most vulnerable people have a combination of low levels of education, poor housing and a lack of involvement with NGOs (particularly NGOs concerned with disaster-related education and preparedness).

(Figure 2 about here)

However, it became clear to us that there are other significant factors that have not been extensively reported or studied before, such as the caste composition of a village and the predominant occupation of the village (Table 2). These variables are typically influenced by key overarching factors, such as the respondent's caste and gender, thereby affecting what type of occupation a person undertakes, what type of village they inhabit, what CBOs they can participate in, and the levels and quality of education they receive. Therefore, even at this very basic level of analysis we can see that caste and gender are key influences upon who is most vulnerable and who is not.

(Table 2 about here)

This led us to look at the different elements of the RAVI and how they are correlated, initially focusing on caste. However, the way in which the index has been constructed means that variables will partly be cross-tabulated with themselves. For example, when the RAVI as a measure of vulnerability is correlated with 'levels of education', to determine whether the least educated are the most vulnerable, there is a danger of being confused by a higher than 'true' correlation, because one of the twenty variables that constitute the RAVI is whether the respondent has attained more than a 
primary level of education. What is important to recognize is that the RAVI is a summary index, that there will inevitably be influences and factors that overlap or are obscured, and that the causality of the variable interrelationships is never completely clear. The RAVI attempts to measure vulnerability by deliberately not looking at each individual variable, but this means that the correlation analysis described below has had to be interpreted with some caution.

\section{VULNERABILITY AND CASTE}

A number of studies have raised concerns about the influence of the hierarchical caste system in creating and perpetuating socio-economic disparities throughout India and particularly in rural India. ${ }^{6}$ The hierarchy of caste classifications were defined by the respondents, with the 'Forward Castes' (FC) then the 'Backwards Castes' (BC) at the top, and the 'Scheduled Castes' (SC) and 'Scheduled Tribes' (ST) at the bottom of the hierarchy. ${ }^{7}$ Our results suggest that these studies may indeed be correct: 50 per cent of the highest caste classification (FC) respondents are in the highest RAVI quartile, and none are in the lowest RAVI quartile; while 44 per cent and 52 per cent of the SC and ST caste members respectively are concentrated in the lower two quartiles of our vulnerability index (see Table 3). The pattern is complex, however, with 56 per cent of the ST caste members in the high average quartile, whereas all other castes are more or less evenly spread between the middle two quartiles. This ST-related anomaly will be discussed in more depth later in this paper.

(Table 3 about here)

\footnotetext{
${ }^{6}$ These studies include Agrawal (2004); Deshpande (2003); DFID (1999); Kabeer (2002); Mencher (1991); Robbins (2000); Searle-Chatterjee and Sharma (1994); Sen Sharma (2000); Venkateswarlu (1986) and reports of human rights institutions, such as Amnesty International (2002) and the Minority Rights Group International (2004).

${ }^{7} \mathrm{We}$ acknowledge that 'caste' is a contested and complex concept and that some commentators will be at odds with the relatively simple version of the 'caste hierarchy' presented here (i.e. not including the influence of jatis or sub-castes). Nonetheless, we believe that it was an important aspect of the project to ground the concepts that were to be used on the perspectives of the respondents, not the researchers. If this perspective of caste turns out to be at odds with other research on caste issues, it should not be viewed as simplistic, but as evidence that the real life manifestations of the caste hierarchy can be extremely different from one location to another.
} 
By disaggregating the RAVI data into its four components (shown in Table 1), Figure 3 shows that the mean percentages of access to assets and public facilities largely match the caste hierarchy, as one might expect. Indeed the pattern is striking and simple: the lower the caste, the less access to assets and facilities that the members have. But the patterns of access to political and social networks and caste classification are much more complex (and perhaps somewhat counter-intuitive): the four components and their five constituent variables that constitute the RAVI are therefore examined in more detail below to establish more clearly the nature of caste related vulnerability disparities.

(Figure 3 about here)

\section{Caste and Access to Assets}

We attempted in our pilot surveys to investigate respondents' daily (and typically informal) income, but the results were unreliable - a problem experienced in many surveys (see Deaton, 2001; Reddy and Pogge, 2002 and the response by Ravallion, 2002, for an extended debate on this topic). For example, a number of landowners living in large pukka (well-built) houses admitted to possessing extensive landholdings and income-generating equipment (such as water pumps, ploughs and auto rickshaws). But they also stated that they typically earned 50 rupees per day (approximately US\$1), the same as an agricultural labourer or fisherman. Since wealth or access to assets can also be difficult to measure objectively, for this study it was assessed in terms of access to key assets such as land and livestock ownership, income-generating equipment and savings, thereby providing a 'triangulated' perspective of asset ownership in that the data were obtained by more than one method, from more than one source and over a period of time.

Whilst Figure 3 shows a clear pattern of assets and caste, Figure 4 illustrates the complexity underlying this simplicity, with marked differences occurring between caste classifications. Assets can be influenced by a respondent's occupation, which is also intrinsically linked to caste (Deliége, 1992, 1999; FAO, 2000; Kinsley, 1993). While the STs appear to exclusively own livestock (due to the traditional role of tribes such as the Erukala in rearing pigs), one third of the FCs own land that is used for the 
cultivation of crops. Nearly one in five ST respondents admitted to possessing some savings while a slightly lower proportion of BC and SC castes stated that they too had savings. None of the FC respondents admitted to having any savings. However - as with income - data regarding savings can be notoriously difficult to obtain and therefore this factor may be unreliable.

(Figure 4 about here)

Fishing castes such as the Agnikulakshatriya and Pattapu fishing communities constitute nearly 80 per cent of the BC sample, which explains why our BC villagers own income-generating assets such as fishing boats and nets (the necessary tools of their occupation). 'Other assets' that are not necessarily used to generate an income, such as motorbikes, televisions and satellite dishes, could be considered to be nonessential or 'luxury' items and are most likely to be owned by the FC castes. The caste hierarchy thus appears to exert a sizeable influence over access to assets, but with specific - and important - local variations.

\section{Caste and Access to Public Facilities}

Ability to access potentially protective public facilities that can promote resilience could be strongly influenced by social institutions and networks. Figure 5 indicates that while the overall relation of caste to public facilities matches the caste hierarchy shown in Figure 3, there are again marked disparities between caste classifications as to who has access to public facilities and who is, therefore, arguably better protected and better prepared to cope with and recover from a disaster. One reason for this is geography: fishing communities are most likely to have access to cyclone shelters because they live nearest to the coast and this is where the shelters have been located. However, many agricultural communities we surveyed live within 5-10 km of the coast and are therefore only marginally less exposed to the impact of a tropical cyclone than the fishing communities.

(Figure 5 about here) 
The FC castes are most likely to have access to a medical centre, aboveprimary level education and (along with STs) to a protected drinking water supply. The only facility to which they do not have the best or equal access is cyclone shelters, for the reasons mentioned above. None of our respondents from the two lowest caste classifications had received any education above basic primary level. However, the STs we surveyed do not have the lowest levels of access to all public facilities. This may be partially explained by the sampling that we necessarily undertook: 70 per cent of the ST respondents involved in this study were located in Nellore district. Nellore has a higher proportion of Scheduled Tribes than other Andhra Pradesh districts (Government of Andhra Pradesh, 2003) and has consequently made concerted efforts to increase the levels of facilities in single caste ST villages. For example, one single caste ST village located in Thotapalligudur mandal in Nellore (see also Table 2) was established in the 1980s specifically for ST families that had been marginalized in multi-caste villages dominated by $\mathrm{BC}$ castes. The village had been given a protected drinking water supply, a primary medical centre and many cyclone resistant houses (although twenty years of sea air had taken its toll on the quality of the housing when the research was conducted in 2002). This is an example of 'positive discrimination' creating circumstances in which vulnerability has been reduced locally by government intervention.

We can thus see that the simple picture presented by Figure 3 is important, but is not the whole story. Access to public facilities contains caste-associated nuances, which may influence vulnerability. For example, as illustrated above, some ST respondents have received 'special treatment'; they live in a purpose-built single caste ST village and have access to facilities such as protected drinking water and cyclone resistant housing. But other ST respondents live in multi-caste villages that are dominated politically (though not necessarily numerically) by FC and BC castes; in these cases, the ST respondents may not have access to a medical centre or school, even though these facilities are located within the village.

Such complexities imply that, if levels of vulnerability are to be accurately assessed, it is necessary to probe deeply, spending time in the villages and gaining insight into the power relationships that are manifest in rural Indian communities. Our research suggests that, overall, access to public facilities follows the same pattern as access to assets: the caste hierarchy has an influence in levels of access but differences 
are less marked towards the bottom of the hierarchy, not least because of past government interventions.

\section{Caste and Access to Political Networks}

Access to key socio-political institutions can enable some people or groups to access vulnerability-reducing resources on a privileged basis. Figure 3 showed that access to these networks generally is fairly uniform across caste groups. However, Figure 6 shows that while FC castes have the most access to political networks overall, the ST classification have the greatest access to networks at State, District and Mandal government levels, despite being at the bottom of the caste hierarchy. This again may be result of the 'positive discrimination' in districts such as Nellore, with their high proportion of STs. So local geography can influence (and to some degree determine) social and political processes.

(Figure 6 about here)

On the other hand, access to networks with potentially influential political leaders are very clearly stratified by caste, with only the highest caste classifications of FC and BC having access to politicians and political leaders. During crisis events, none of the respondents, irrespective of gender or caste, could boast relationships with political leaders. However, this situation may change if a crisis event occurs in the run up to an election, where political involvement in the assistance of communities may be more visible, if not necessarily well directed (Reddy and Sastry, 1992). The castes with the lowest levels of state/government political networks are likely to compensate for this by utilizing local networks with the Panchayat and community leaders, to which they appear to have the greatest access (Figure 6).

Relationships with Mandal officials are potentially important for coping in a crisis scenario because these officials are, on a local scale, influential and powerful decision makers and distributors of resources (Reddy et al., 1996). We enquired about the resilience of these networks; significantly, only 13 per cent of relationships with Mandal officials are lost during a crisis event such as the 1996 cyclone, which reflects 
well on the involvement of Mandal officials in such situations. Access to Mandal officials in our samples was not significantly affected by caste, social status or gender.

Since Panchayat committees and village elders are key institutions responsible for the distribution of village level resources in a crisis (Reddy et al., 1996), it is crucial that these institutions should be unbiased in the ways that resources are distributed, to avoid nepotism and corruption (Narayanasamy et al., 2000). That this is often not the case was highlighted by one respondent: 'The village elders and other rich men distributed rice for selected people only and not for all the villagers; they only assisted influential people. The village elders were only interested in helping the rich people because they didn't distribute the relief supplies equally' (Female, BC, from a single caste village). Consequently, it may be very important for villagers to maintain good relationships with village elders, even in the relatively homogeneous single caste villages. For example, one woman explained that her husband died during the 1996 cyclone but she did not receive the compensation to which she was entitled because of long-running disputes with her village elders:

The village elders didn't send my husband's name to the appropriate government department. Previously, we had some clashes with the village elders, particularly with the ration dealer in my village. The ration dealer is involved with some corruption in my village and my husband had witnessed some of that corruption. My husband then went and complained to some government people and as a consequence my husband became the village elder's enemy. That is why I did not receive compensation for my husband's death. If I go to the village elders for help, they will not help me. (Female, BC, from a single caste village)

We thus begin to see another level of complexity hidden within the data. It is clearly important to possess social networks with potentially influential political institutions, but it is just as important to be on 'good terms' with these institutions over long periods: the network itself is just the starting point. When resources are finite and the government's policies and/or mechanisms are ineffective (through lack of interaction with stakeholders and recipients of development projects or simply due to corruption and nepotism) those without good political connections will miss out and will be more vulnerable to the hazards that they face. 


\section{Caste and Access to Social Networks}

Our data suggest that those without strong political networks or good access to assets or public facilities seek alternative avenues of support; these avenues are typically social networks with informal social institutions such as friends, family and CBOs (Figure 7). Figure 3 showed that the three lower caste groups have more developed social networks than the FC groups. The SC castes are most likely to have family links within their village, while ST tribals are least likely to have intra-village networks but have the highest levels of family networks in another village (Figure 7). This indicates that STs (many of whom are migrant workers) are likely to spread themselves as family units over a wide geographical area to maximize access to diverse seasonal employment opportunities as a strategy to cope on a day-to-day basis.

(Figure 7 about here)

Access to family members in other villages is predominantly defined by gender rather than caste; more than two-thirds of women have these types of networks, while less than one-fifth of men claim such inter-village links. ${ }^{8}$ This may be important because such networks can allow villagers access to institutions from which they may be barred in their village of residence. Thus ties with natal kin in other villages allow women to have access to potentially useful institutions such as CBOs and NGOs. For example, 27 per cent (ten out of thirty-seven cases) of women living in one of the relatively under-developed villages that we sampled, which had no NGO activity of its own, are actually involved with an NGO via external family links.

Links and networks outside the immediate locality provide resilience at times of disaster - somewhere to send dependants, alternative sources of livelihood. Those born outside their current village have the greatest social contacts in another village (72 per cent) and these are predominantly women ( 69 per cent). ${ }^{9}$ It appears likely, in

\footnotetext{
${ }^{8}$ Statistics: $\chi^{2}=81.187$; significant, $\mathrm{p}<0.01$

${ }^{9}$ This is largely because 56 per cent of the female respondents were born outside their village of residence, compared to 2 per cent of males. It is the tradition in rural India (and to some extent in urban India), when intra-caste (and intra-jati) marriages take place, that suitable brides will be sought outside the groom's village to minimize the chances of intra-family
} 
parallel with these results, that villagers' involvement with NGOs and CBOs - which is caste related - could be a direct result of greater awareness of entitlements through contact with family members in other villages that have increased resources through access to these organizations.

In our case study areas, we found that NGOs only operate in single caste fishing villages. The BCs and STs that typically live in single caste villages are thus more likely to benefit from the assistance of NGOs in a pre-disaster scenario and in disasters themselves, as the NGOs tend to focus relief efforts on villages in which they already operate. Social networks can thus represent an important resource, and their distribution has a strong gender correlation: there is also a caste dimension, but not a strong one. When the poor and powerless lower castes are marginalized they are forced to utilize their social networks, which tend to be informal. These informal social networks are typically accessed by women via their direct or indirect membership and involvement with CBOs and NGOs.

\section{VULNERABILITY AND NON-CASTE VARIABLES}

It is almost impossible to discuss caste without including variables that are apparently not caste related such as gender, village type and networks with NGOs. However, it is also nearly impossible to discuss non-caste variables without reference to the influence of caste, because caste and all other aspects of rural Indian society are so intertwined. In this sense, it is surprising that the role of caste is underplayed by many authors, such as Bhalla and Lapeyre (1997), Das (2004), Gaiha et al. (2001), John (2000), and in many World Bank publications (such as World Bank 1997, 1999 and 2001). Indeed, an extensive review of literature in sociology, gender studies, social exclusion, rural development, socio-politics, disaster management and caste in India suggested a decline in caste-referenced discussion since the 1990s. This may reflect a view that caste is of diminishing significance in rural India, but our results appear to be at variance with that perspective.

marriages. After such a marriage the bride will typically live in the village of her husband's family. 


\section{Gender, NGOs and Vulnerability}

Much of the Indian sociological literature suggests that women in rural India are hindered by constraints on their social status and potential opportunities (Agarwal, 1990, 1997, 2001; Gupta, 1991; Martin and Lemon, 2001; Moore, 1998). Typically, gender inequalities have meant that women take on the burden of family life as a result of traditionally determined roles in household and village affairs. Relatively unrepresentative levels of women in the Panchayat (Moore, 1998), and the exclusion of women from traditional institutions (Agarwal, 2001; Beck, 1995; Moore, 1998; Robbins, 2000), and even from the newly created participatory institutions (Agarwal, 1997; Deepa et al., 2000), have all contributed to maintaining the role of women as 'second class citizens' in rural village life.

These assertions are generally substantiated by our results (Figure 8). Men are twice as likely as women to possess networks with high level government officials, although women have more networks with local community leaders than men, possibly as a substitute. The surveys included in Bosher (2005) indicate that women rely on intermediary social networks with institutions such as CBOs, women's groups and community leaders to access high level government officials. Men, in contrast, were more likely to interact with government officials directly.

(Figure 8 about here)

As suggested above, other social networks can also be important to women in reducing vulnerability, primarily through informal networks with family, participatory institutions and NGOs (Agarwal, 1991; Enarson, 2000; Moore, 1998; Moore, 1990). Our data suggest that when women are involved with organizations such as NGOs and CBOs they can significantly improve their personal resilience and the resilience of their family through the adoption of income diversification strategies (such as fish pickling and chutney making), by access to credit and savings, and through support for small business ventures. When NGOs are operating in villages, women are four times more likely than men to be involved with NGO activities. This is because many NGO programmes are targeted at females, through the foundation of women's groups (mahila sanghas) focused on providing women with improved education and general knowledge, and increasing their access to formal financial services such as credit and 
savings schemes. Men are less likely to participate with NGOs due to scepticism towards participatory, 'pro-women' projects that fundamentally challenge traditional power structures. One in five males in our surveys said that 'problems' occurred when women became involved with $\mathrm{NGO}$ and $\mathrm{CBO}$ activities because, for example, 'women become so busy that they neglect their household and child care duties'. Some 8 per cent of females also recognized 'problems', largely because attending meetings meant that they missed opportunities for paid and unpaid work.

Men are also less aware of NGO activities when they are operating in their village. For example, 61 per cent of the men we interviewed in villages with recent NGO activity were not aware of these activities, while 80 per cent of females interviewed in the same villages were aware of NGO activities, even if they did not participate. Our data show, therefore, that gender can play an important role in reducing vulnerability, and that women are gaining resilience as a result of a range of social and economic processes, largely operating at a very local level.

\section{Education, Caste and Vulnerability}

More education generally leads to increased resilience (Menon-Sen and Shiva Kumar, 2001). Our data show that villagers with higher than primary level education have substantially greater access to public facilities and political networks (Table 1) than respondents with less than primary level education (Figure 9). Those with low levels of education (predominantly the lower caste groups) have proportionately more social networks, possibly in an attempt to compensate for their lack of access to the other resources such as public facilities and political networks.

(Figure 9 and Table 4 about here)

Other significant disparities regarding levels of education are again associated with caste (Table 4). On average, 61 per cent of the villagers we surveyed have received no education of any kind; however, this applies to only 18 per cent of the FC respondents. None of those belonging to the lowest caste classifications had attained 
more than a primary level education. The vast majority of the SC and ST respondents (thirty-seven out of thirty-eight cases) had never been to school or had only completed 'a few' years of primary education.

These results suggest that the central and state governments' attempts to reduce illiteracy in rural India have so far been ineffective, and they also indicate how everyday pressures on the poorest families in these communities force them to continue to send their uneducated children to earn a wage rather than to obtain any education. The situation is different for the highest caste classification (FC), where 19 per cent of our sample had been educated to secondary school level or above, and 9 per cent had received college or university education.

Despite uncertainties about the reasons for these disparities one thing is apparent: levels of educational attainment are significantly influenced by a respondent's caste classification. This in turn can influence the types of resources to which a rural villager has access, because villagers with the higher levels of education are more likely to have access to public facilities, political networks and material assets, all of which significantly reduce their vulnerability. More government effort in educating lower caste groups must be a priority, so that the benefits of reductions in vulnerability reach those who need them the most.

\section{Age and Vulnerability}

A number of studies (Guillette, 1991; O’Riordon, 1986; UNICEF, 1989) have concluded that the young and the old are among the most vulnerable to any hazards faced by their communities. Our data does not support this in any clear way: there is no significant difference in the age profile of those in the lowest RAVI quartile (the most vulnerable) and those in the highest quartile (the least vulnerable) (Table 5). Of the villagers studied, 54 per cent of those over sixty years old were still working to earn a wage, with 29 per cent employed in manual labour (of the non-workers, 25 per cent were retired and 21 per cent undertook unpaid housework ${ }^{10}$ ). Although our data indicate that age is not a significant factor in determining a respondent's access to the key resources listed in Table 1, we found that respondents aged fifty years and over

${ }^{10}$ Statistics: $\chi^{2}=105.180$; significant, $\mathrm{p}<0.01$ 
were the least likely to seek assistance from the government or aid agencies during and after a crisis, irrespective of caste or socio-economic status (Bosher, 2005). So there may well be an age effect on vulnerability that is more subtle than can be detected in the kind of analysis presented here.

(Table 5 about here)

On the other hand, when researching Indian society it is difficult to disentangle the individual from the household because 'the Indian social structure is nonindividualistic, basically collective, never free of the intricate linkages with others' (Gangrade, 1998: 131). It is therefore possible that the similar profiles in Table 5 reflect this, with the extended family living arrangements leading to the pooling of access to assets, facilities and networks across age groups.

\section{CONCLUSIONS}

The influence of caste on access to resources and hence vulnerability is likely to be different from one region/state/district to the next and the results from this research are not necessarily applicable across the whole of India. This study merely provides a vignette of the complexities in Indian society within the context of coastal Andhra Pradesh.

Nonetheless, the findings of this context-specific research indicate that caste appears to be a key factor influencing who is vulnerable to the many hazards faced in coastal Andhra Pradesh: it influences who owns assets, who can access public facilities, who has specific political connections and who has particular supportive social networks. Previous studies (Rashid, 2000; Winchester, 1992; World Bank, 2001) have looked at asset ownership, and seen that this affects vulnerability, as we have also found. But we can now see that this factor should not be seen in isolation from the many other drivers of vulnerability. Access to public facilities and to political and social networks can provide, firstly, the vehicles through which caste-related inequalities persist and, secondly, the 'social capital' assets themselves that can enhance resilience and reduce vulnerability in a number of important ways, not least for the lowest caste groups. 
The lower castes appear to be more vulnerable because they lack access to important public resources and opportunities to reduce their vulnerability and improve their plight. These castes can additionally be marginalized and made more vulnerable when they live in multi-caste villages where higher castes dominate the decisionmaking processes to the extent that the vested interests of the powerful and wealthy higher castes can be perpetuated. Indeed, it has been observed that in India it is not exclusion from society that effects poverty, but rather inclusion in a society based on strict hierarchical structures (IILS, 1996).

Typically, the poorest villagers we studied have low access to assets precisely because they are low caste; this has proved contentious in past studies on this topic (Abercrombie et al., 2000). The correlation found in this study between caste status and economic status has been suggested before (DFID, 1999; Mencher, 1974, 1991; Robbins, 2000; Searle-Chatterjee and Sharma,1994), but there have been few studies that have supported their claims via sound or contemporary empirical evidence. This issue of the lack of evidence has been raised by the Minority Rights Group International (2004), who argue that organizations such as the World Bank, United Nations and ILO have seriously understated the socio-economic problems associated with caste disparities in rural India. Our findings suggest that caste does indeed influence socio-economic disparities in coastal Andhra Pradesh, and consequently influences levels of vulnerability and the 'potential resilience' of these individuals to large-scale disasters and small-scale crises.

The poor and powerless lower castes (those with poor access to political networks) are marginalized, and fall back on their social networks. These latter networks are typically accessed by women via their involvement with CBOs and NGOs. This observation highlights the importance of women's labour (Moser and Mcllwaine. 1997) and social networks (Agarwal, 1990; Moore, 1990) in the process of vulnerability reduction but it also points to issues concerning the poor rural male and whether they need the kind of extra assistance that women have now attracted.

Geography is also important. The caste situation appears to be different in single-caste villages. Here people who are low on the Varna hierarchy, such as STs, can obtain relatively better access to public facilities and political networks than STs who inhabit multi-caste villages. The disparities observed between single-caste and multi-caste villages can be exacerbated when NGOs are reticent to operate in the perceived social complexity of multi-caste villages. 
According to our study, caste appears to have a significant influence on who does and who does not have access to the resources that can reduce levels of vulnerability and increase resilience to major disasters such as cyclones, but also to the everyday crises that continually disrupt the lives of people in rural coastal India. Of course it is not caste per se that has these effects, but the stigma, status and social processes that inevitably accompany it. What can be done to mitigate this situation is far from clear, but at least our diagnosis may help others to find some new and better solutions to this age-old problem. 


\section{REFERENCES}

Abercrombie N., S. Hill and B. S. Turner (2000), The Penguin Dictionary of Sociology London, Penguin Books ( $4^{\text {th }}$ edn $)$.

Agarwal, B. (1990) 'Social Security and the Family in Rural India: Coping with Seasonality and Calamity', Journal of Peasant Studies 17(3): 341-412.

Agarwal, B. (1991) 'Social Security and the Family: Coping with Seasonality and Calamity in Rural India', in E. Ahmed, J. Dreze, J. Hills and A. Sen (eds) Social Security in Developing Countries, 171-244. Oxford, Clarendon Press.

Agarwal, B. (1997) ‘Environmental Action, Gender Equity and Women’s Participation', Development and Change 28(1): 1-44.

Agarwal, B. (2001) 'Participatory Exclusions, Community Forestry, and Gender: An Analysis for South Asia and a Conceptual Framework', World Development 29(10): $1623-48$.

Agrawal, A. (2004) 'The Bedias are Rajputs: Caste Consciousness of a Marginal Community', Contributions to Indian Sociology (n.s.) 38(1-2): 221-46.

Amnesty International (2002) 'Amnesty International Report: India'. POL 10/001/2002. Available online: http://web.amnesty.org/web/ar2002.nsf/asa/india!Open\#bottom (accessed 26 December 2004).

Beck, T. (1995) 'The Green Revolution and Poverty in India: A Case Study of West Bengal', Applied Geography 15(2): 161-81.

Bhalla, A. and F. Lapeyre (1997) 'Social Exclusion: Towards an Analytical and Operational Framework', Development and Change 28(3): 413-33. 
Bosher, L.S. (2005) “"The Divine Hierarchy”: The Social and Institutional Elements of Vulnerability in South India'. PhD Thesis, Middlesex University, London.

Bosher, L.S. (2007) Social and Institutional Elements of Disaster Vulnerability: The Case of South India. Academica Press, Bethesda.

Boyce, J. K. (2000) 'Let Them Eat Risk? Wealth, Rights and Disaster Vulnerability', Disasters 24(3): 254-61.

Buckle, P., G. Marsh and S. Smale (2000) 'New Approaches to Assessing Vulnerability and Resilience', Australian Journal of Emergency Management 15(2): $8-14$.

Coles, E. and P. Buckle (2004) 'Developing Community Resilience as a Foundation for Effective Disaster Recovery', Australian Journal of Emergency Management 19(4): 6-15.

Das, R. (2004) 'Social Capital and Poverty of the Wage-labour Class: Problems with the Social Capital Theory', Transactions of the Institute of British Geographers 29(1): $27-45$.

Davies, S. and M. Hossain (1997) 'Livelihood Adaptation, Public Action and Civil Society: A Review of the Literature'. IDS Working Paper 57. Brighton: Institute of Development Studies, University of Sussex.

Deaton, A. (2001) 'Counting the World's Poor: Problems and Possible Solution', World Bank Research Observer 16(2): 125-47.

Deepa, N., K. Schafft, A. Rademacher and S. Koch-Schulte (2000) Voices of the Poor: Can Anyone Hear Us? New York, Oxford University Press.

Deliége, R. (1992) 'Replication and Consensus: Untouchability, Caste and Ideology in India', Man (n.s.) 27(1): 155-73. 
Deliége, R. (1999) The Untouchables of India. Oxford: Berg.

Deshpande, S. (2003) Contemporary India: A Sociological View. New Delhi: Penguin Books.

DFID (1999) 'India: Country Strategy Paper 1999’. London: Department for International Development.

Enarson, E. (2000) 'Gender and Natural Disasters'. ILO Infocus Programme on Crisis Response and Reconstruction Working Paper No 1. Geneva: International Labour Organization.

FAO (2000) 'Report of the Government of India/Government of Andhra Pradesh/ FAO Workshop on Measures to Reduce Loss of Life during Cyclones, Vishakapatnam, Andhra Pradesh, India, 4-6 March 1999’. FAO Fisheries Report No 622. Rome: Food and Agriculture Organization of the United Nations.

Gaiha, R., I. Katsushi and P. D. Kaushik (2001) 'On the Targeting and CostEffectiveness of Anti-Poverty Programmes in Rural India', Development and Change 32(2): $309-42$.

Gangrade, K. D. (1998) 'Social Networks and Crisis Management in Indian Families: A Personal Account', in A. M. Shah, B. S. Baviskar and E. A. Ramaswamy (eds) Social Structure and Change, Volume 5: Social Structure and Change - Religion and Kinship, 111-134. New Delhi: Sage.

Government of Andhra Pradesh (2003) 'Literacy Rates by Residence and Sex: State, District and Mandal, 2001'. AP 2001 Census Figures: Paper 2, Table 5. Government of Andhra Pradesh, Hyderabad

Guillette, E. A. (1991) 'The Impact of Recurrent Disaster on the Aged of Botswana'. Paper presented at the $50^{\text {th }}$ Annual Meeting of the Society for Applied Anthropology, Charleston, South Carolina, 13-16 March. 
Gupta, D. (1991) 'Hierarchy and Difference: An Introduction', in D. Gupta (ed.) Social Stratification, 1-21. Delhi: Oxford University Press.

Hearn Morrow, B. (1999) 'Identifying and Mapping Community Vulnerability', Disasters 23(1): 1-18.

IILS (1996) Social Exclusion and Anti-Poverty Strategies. Geneva: International Institute for Labour Studies.

John, V. (2000) 'Political and Cultural causes of Corruption', in N. Narayanasamy, M. P. Boraian and M. A. Jeyaraju (eds) Corruption at the Grassroots: The Shades and Shadows, 61-69. New Delhi: Concept Publishing.

Kabeer, N. (2002) 'Safety Nets and Opportunity Ladders: Addressing Vulnerability and Enhancing Productivity in South Asia', Development Policy Review 20(5): 589614

Kinsley, D. R. (1993) Hinduism: A Cultural Perspective. Upper Saddle River, NJ: Prentice-Hall ( $2^{\text {nd }}$ edn).

Kohli, A. (1990) Democracy and Discontent: India's Growing Crisis of Governability. Cambridge: Cambridge University Press.

Kothari, R. (ed.) (1986) Caste in Indian Politics. London: Sangam Books.

Marsh, G. and P. Buckle (2001) 'The Concept of Community in Emergency Management', Australian Journal of Emergency Management 16(1): 5-7

Martin, A. and M. Lemon (2001) 'Insights and Applications: Challenges for Participatory Institutions: The Case of Village Forest Committees in Karnataka, South India', Society and Natural Resources 14(7): 585-97. 
Mencher, J. (1991) 'The Caste System Upside Down' in D. Gupta (ed.) Social Stratification, 84-92. Delhi: Oxford University Press.

Mencher J., (1974), “The Caste System Upside Down, or The Not-so-Mysterious East", Current Anthropology 15:469-93

Menon-Sen, K. and A. K. Shiva Kumar (2001) 'Women in India: How Free? How Equal?'. Report Commissioned by the Office of the Resident Co-ordinator in India. New Delhi: United Nations.

Minority Rights Group International (2004) 'Discrimination on the Grounds of Work and Descent: Sub-Commission on the Promotion and Protection of Human Rights: 53rd Session'. Available online: http://www.minorityrights.org/International/int_stat_detail.asp?ID=1 (accessed on 15 July 2004).

Moore, E. (1998) Gender, Law and Resistance in India. Tucson, AZ: University of Arizona Press.

Moore, G. (1990) ‘Structural Determinants of Men’s and Women’s Personal Networks', American Sociological Review 55 (5): 726-735

Moser, C. and C. Mcllwaine (1997) Household Responses to Poverty and Vulnerability. Volume 3: Confronting Crisis in Commonwealth, Metro Manila, the Philippines. Urban Management Programme Publication No 23. Washington, DC: The World Bank.

Narayanasamy, N., M. P. Boraian and M. A. Jeyaraju (eds) (2000) Corruption at the Grassroots: The Shades and Shadows. New Delhi: Concept Publishing.

O’Riordon, T. (1986)'Coping with Environmental Hazards', in R. Kates and I. Burton (eds) Geography, Resources and Environment, Vol. 2, pp. 272-309. Chicago, IL: University of Chicago. 
Parasuramam, S. and P. V. Unnikrishnan (eds) (2000) India Disasters Report:

Towards a Policy Initiative. New Delhi: Oxford University Press.

Rashid, S. F. (2000) 'The Urban Poor in Dhaka City: Their Struggles and Coping Strategies during the Floods of 1998', Disasters 24(3): 240-53.

Ravallion, M. (2002) 'How Not to Count the Poor? A Reply to Reddy and Pogge'. Available online: http://www.columbia.edu/ sr793/wbreply.pdf

Reddy, S. G. and T. W. Pogge (2002) 'How Not to Count the Poor' (Version 3.0). New York: Barnard College (mimeo).

Reddy, A. V. S. and K. R. Sastry (1992) 'The Politics of Disaster: Public Pressure and State Response to Cyclone Relief in Andhra Pradesh', Journal of Disaster Management 4(3): 123-30.

Reddy, A. V. S., V. K. Sharma and M. Chittoor (2000) Cyclones in Andhra Pradesh: A multidisciplinary study to profile cyclone response in coastal Andhra Pradesh, India. Hyderabad: Bookline.

Reddy, A. V. S., B. K. Thapliyal and K. R. Sastry (1996) 'Disaster Mitigation through People's Participation: Role of Local Self Government Institutions', Asia-Pacific Journal of Rural Development 6(2): 15-34.

Robbins, P. (2000) 'The Rotten Institution: Corruption in Natural Resource Management', Political Geography 19(4): 423-43.

Searle-Chatterjee, M. and U. Sharma (eds) (1994) Contextualising Caste: PostDumontian Approaches. Sociological Review Monographs. Oxford: Blackwell.

Sen, A. (1981) Poverty and Famines: An Essay on Entitlement and Deprivation. Oxford: Clarendon Press. 
Sen Sharma, D. (2000) 'Hindu Values', in J. Cauquelin, P. Lim and B. Mayer-König (eds) Asian Values: Encounters with Diversity, pp. 106-17. Richmond, UK: Curzon.

UNICEF (1989) Children on the Frontline: The Impact of Apartheid, Destabilisation and Warfare on Children in Southern and South Africa. New York: UNICEF.

Venkateswarlu, D. (1986) 'Socio-Economic Differences between Harijans, MiddleCastes and Upper-Castes: A Comparative Study of Six Villages in Andhra Pradesh', The Eastern Anthropologist 39(3): 210-23.

Warmington, V. (1995) 'Disaster Reduction: A Review of Disaster Prevention, Mitigation and Preparedness'. Ottowa: Reconstruction and Rehabilitation Fund of the Canadian Council for International Co-operation.

Winchester, P. (1992) Power, Choice and Vulnerability: A Case Study in Disaster Mismanagement in South India, 1977-1988. London: James and James Science Publishers.

Wisner, B., P. Blaikie, T. Cannon and I. Davis (2004) At Risk: Natural Hazards, People’s Vulnerability, and Disasters: Second Edition. London: Routledge.

World Bank (1990) World Development Report 1990. Washington, DC: The World Bank.

World Bank (1997) 'Emergency Cyclone Recovery Project Will Help Andhra Pradesh Rebuild and Stave off Future Destruction'. World Bank Official Press Release, 7 May. Available online:

http://lnweb18.worldbank.org/sar/sa.nsf/6062ad876fb8c066852567d7005d648a/85a78 ca451f90d6d852568fd0066c918?OpenDocument (accessed 5 March 2003).

World Bank (1999) 'Consultations with the Poor: India 1999'. A study commissioned by Poverty Reduction and Economic Management Network of the World Bank, PRAXIS-Institute for Participatory Practices, Patna 
World Bank (2001) World Development Report 2000/20001: Attacking Poverty. Oxford: Oxford University Press.

Lee Bosher, Department of Civil and Building Engineering, Loughborough University, Leicestershire, LE11 3TU, UK (e-mail: L.Bosher@lboro.ac.uk ) Current research is focused on improving the resilience of the built environment to extreme natural and human-induced hazards through the involvement of end users and key stakeholders. Forthcoming books include; the 'Social and Institutional Elements of Disaster Vulnerability: The Case of South India', and 'Hazards and the Built Environment: Attaining Built-in Resilience'.

Edmund Penning-Rowsell, Flood Hazard Research Centre, Middlesex University, UK (e-mail: e.penning-rowsell@mdx.ac.uk ) 30 years of research that has focused on the impacts of floods, optimising policy responses to floods, the funding of flood defence investment, and the role of emergency services during major hazard events.

Sue Tapsell, Flood Hazard Research Centre, Middlesex University, UK (e-mail: s.tapsell@mdx.ac.uk )

Recent research has focused on the human 'intangible' health and social impacts of flooding, the social performance of flood warning systems, community resilience to flooding, and stakeholder communication and engagement in flood risk management. 
Figure 1:

\section{Location of Andhra Pradesh and the Case Study Districts}

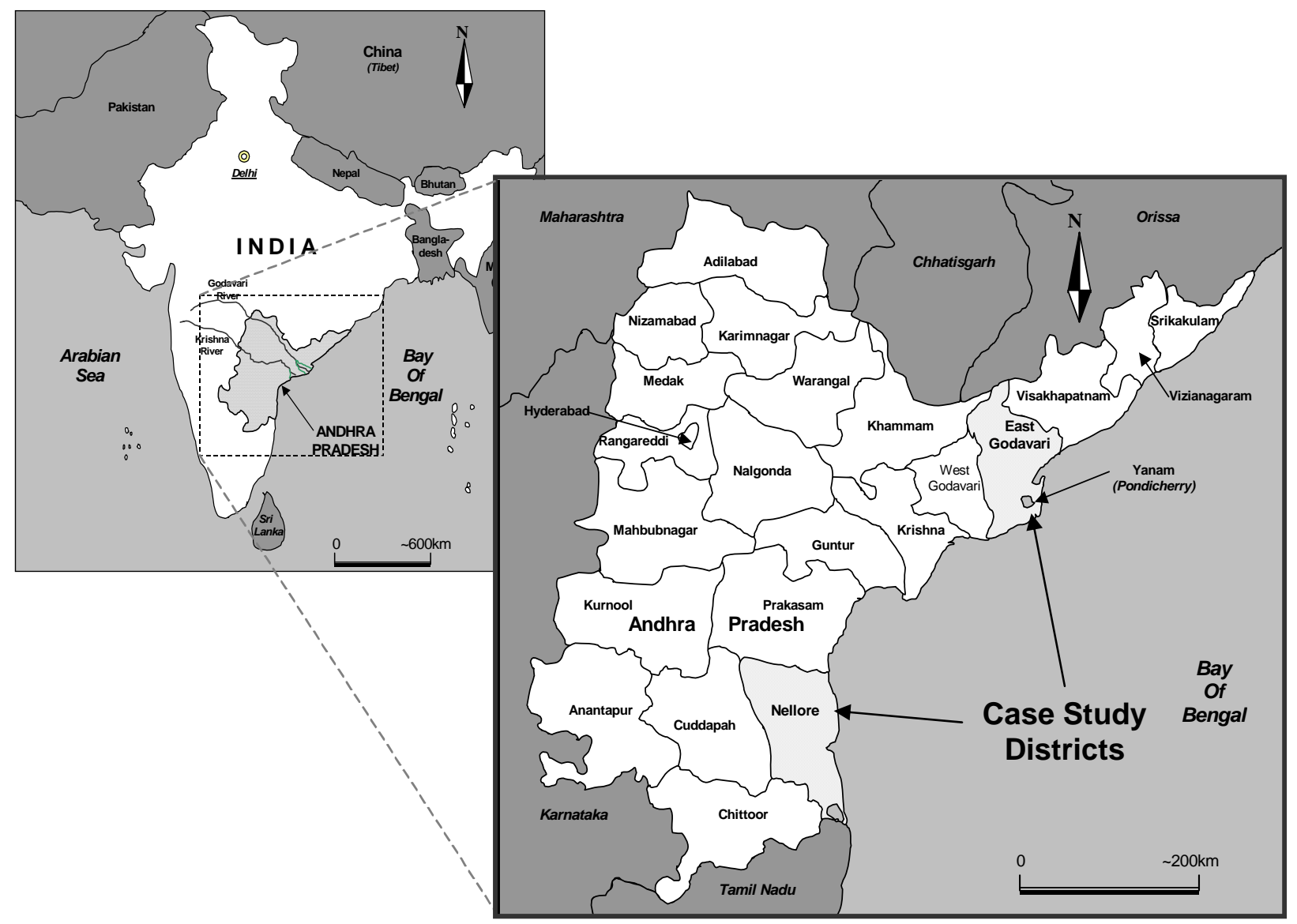

Source: Bosher 2005 
Figure 2:

'Resource Accessibility Vulnerability Index' (RAVI) Frequency Distributions

Total RAVI [four components]
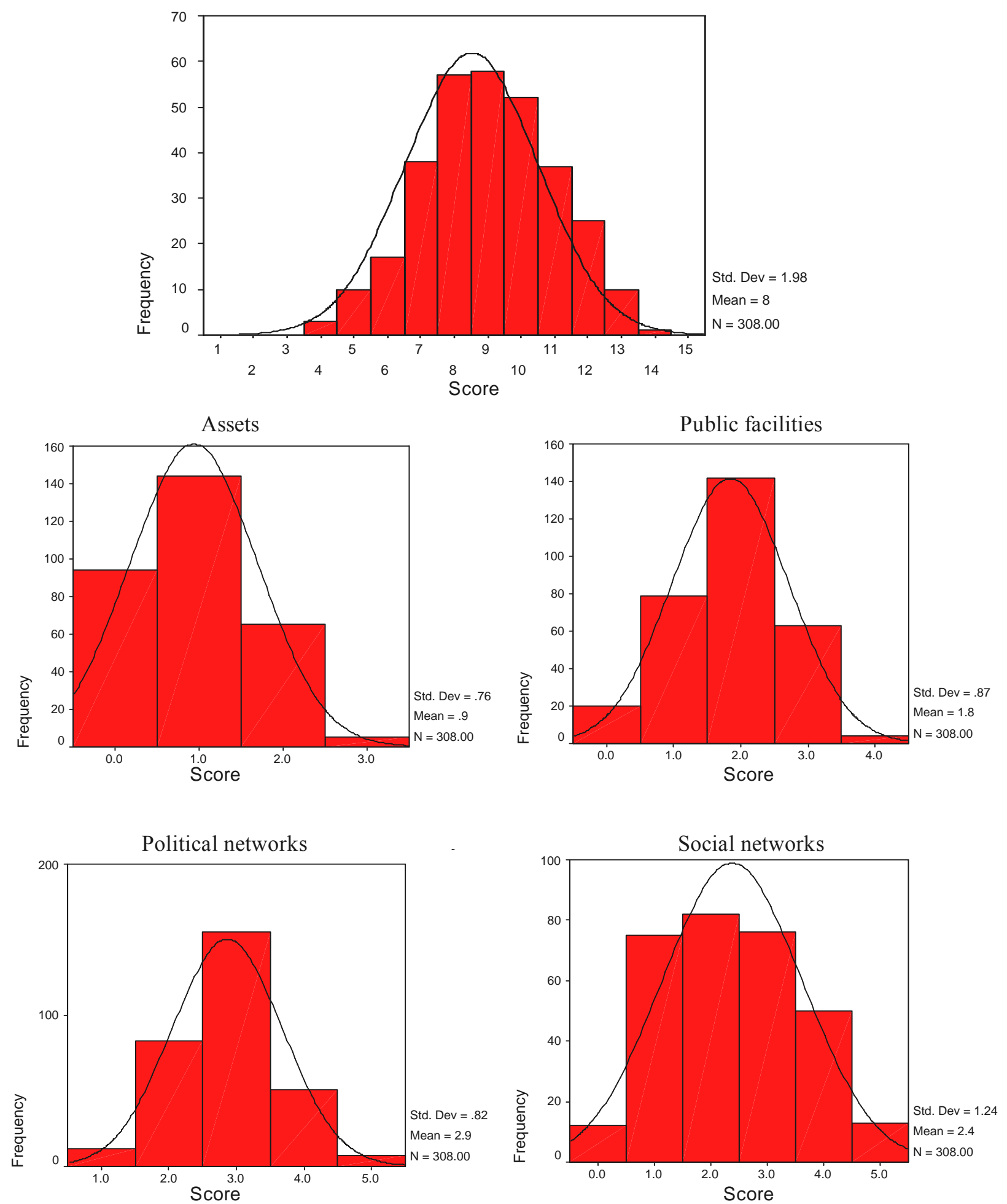
Figure 3:

Mean Percentage Access to the Four Determinants of Vulnerability by Caste Classification

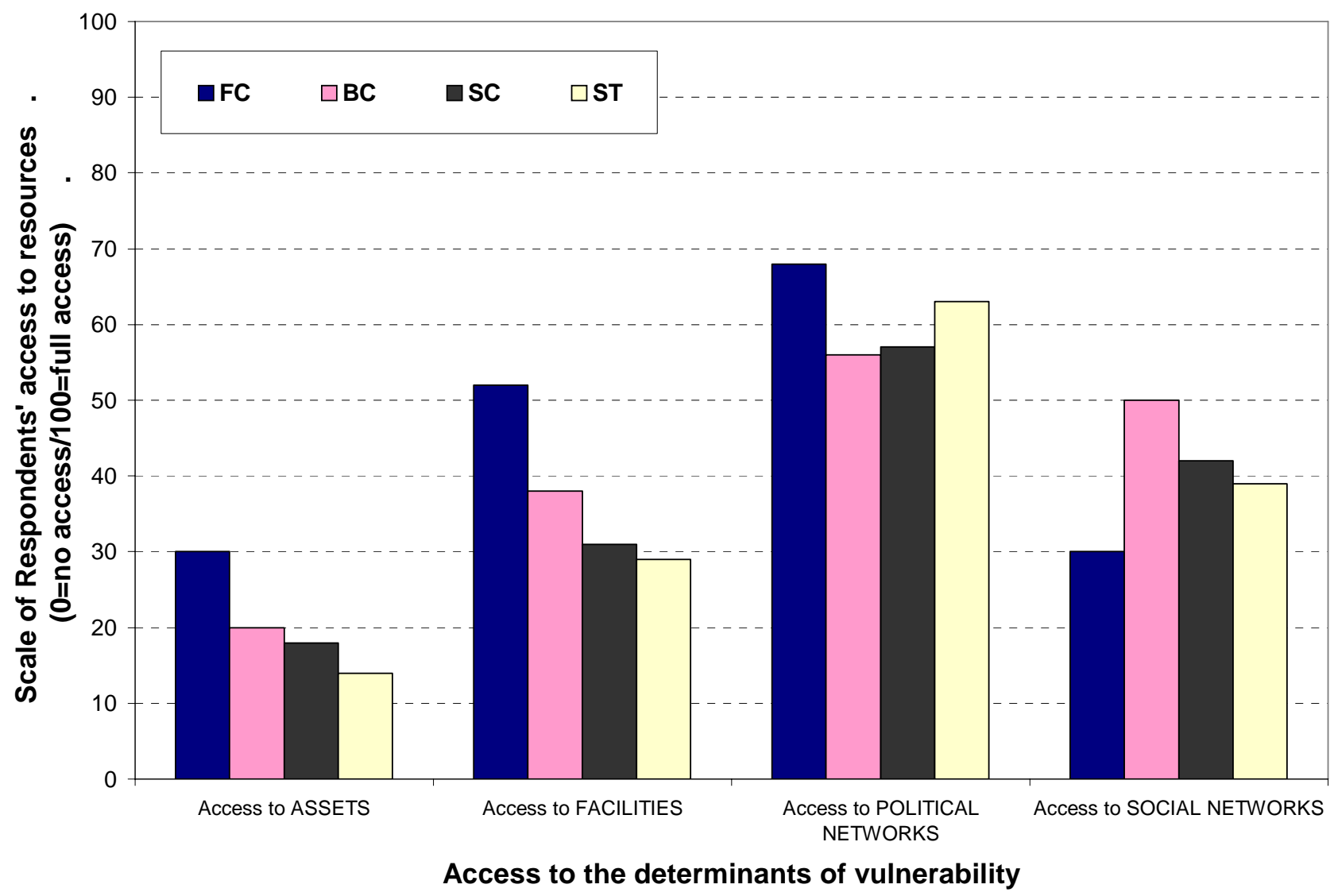


Figure 4:

Access to assets by Caste classification

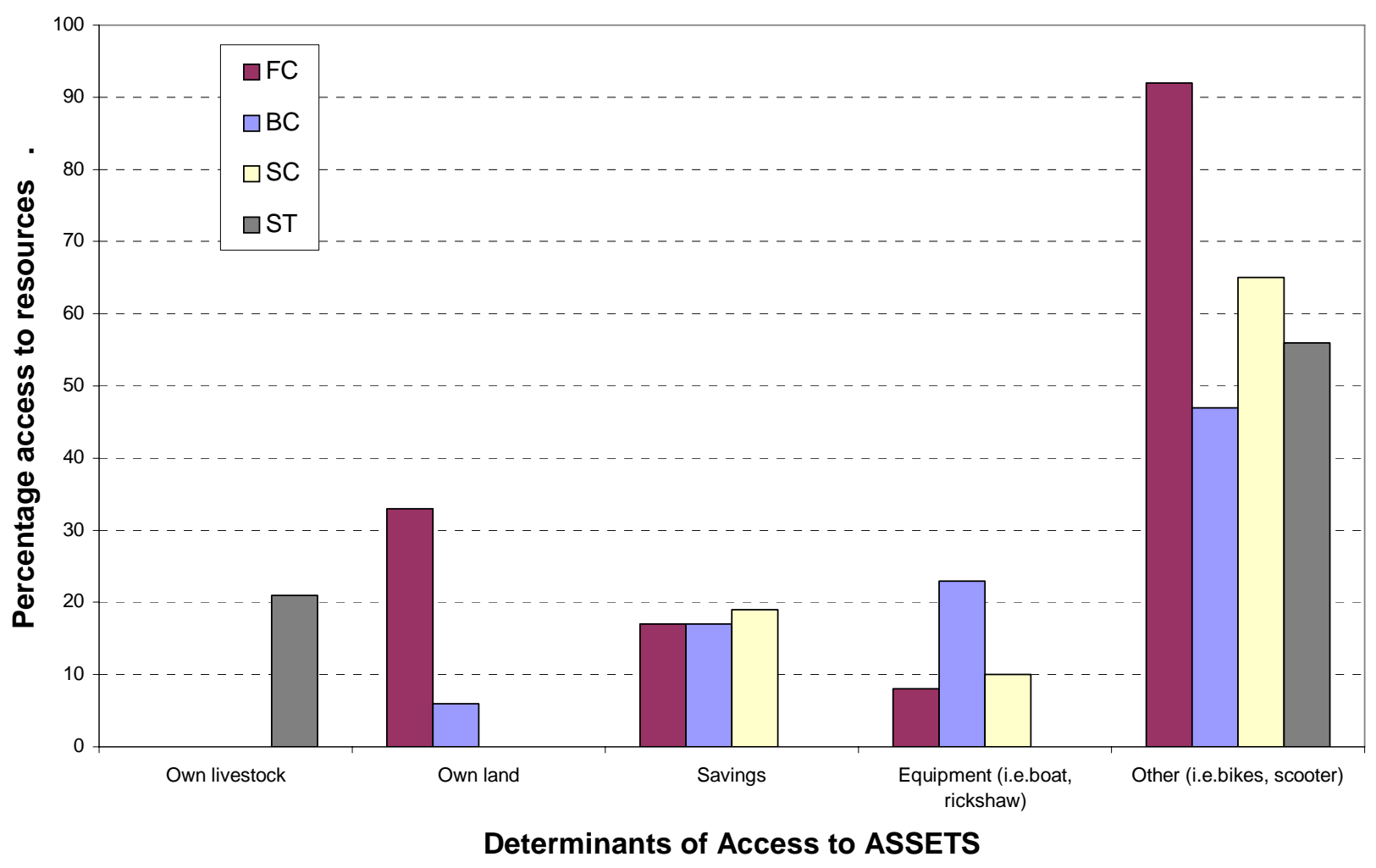


Figure 5:

Access to public facilities by caste classification

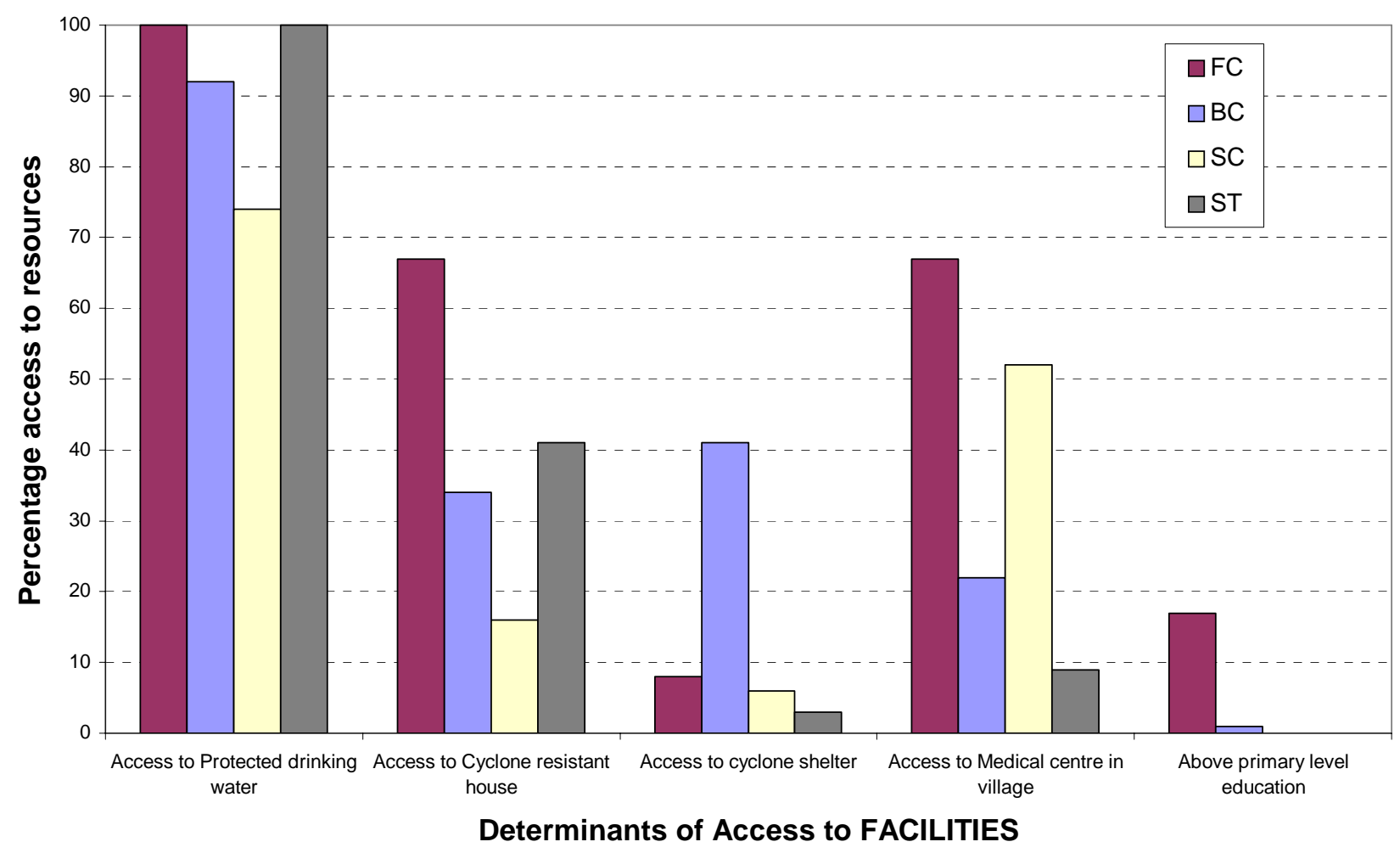


Figure 6:

Access to political networks by caste classification

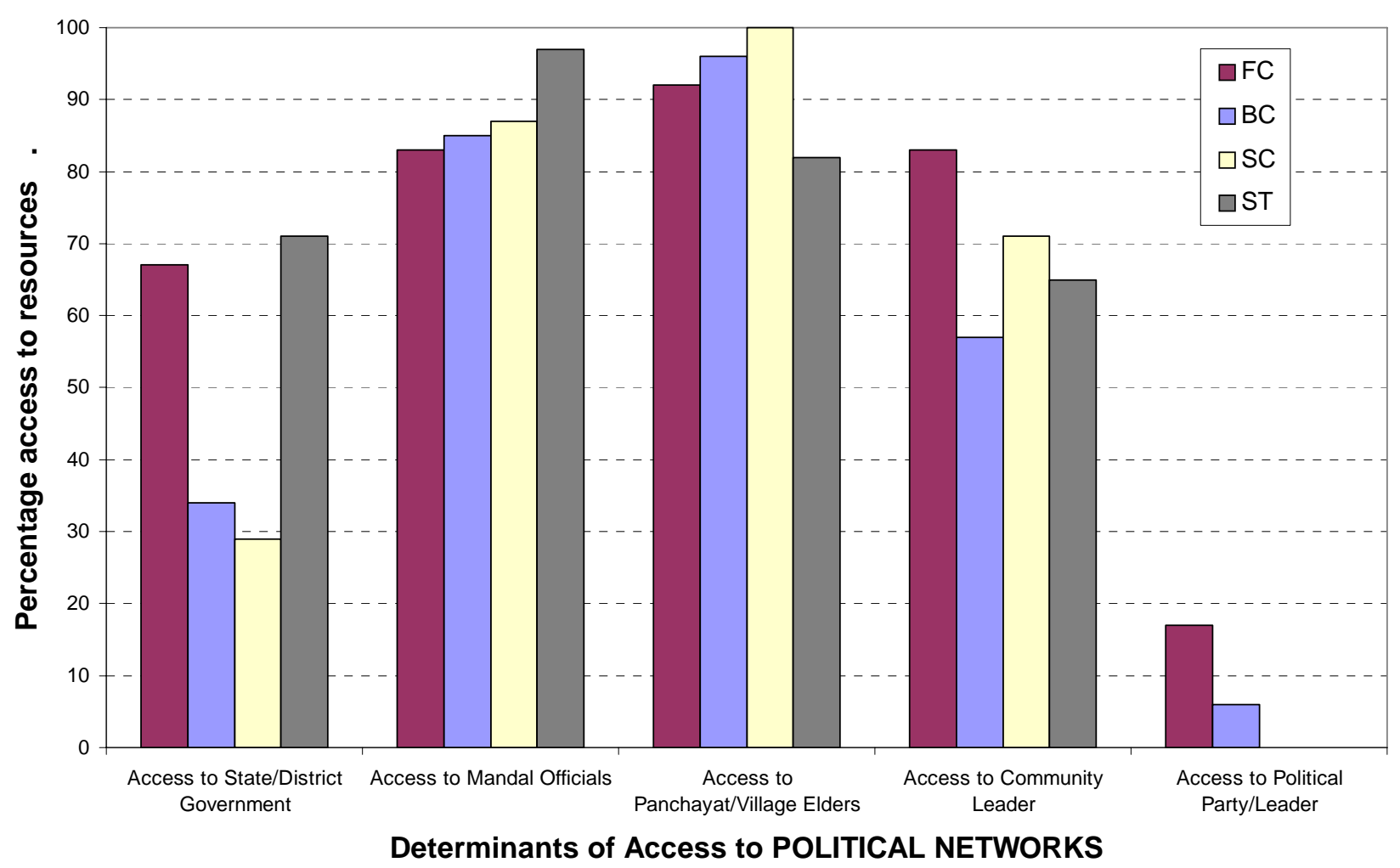


Figure 7:

Access to social networks by caste classification

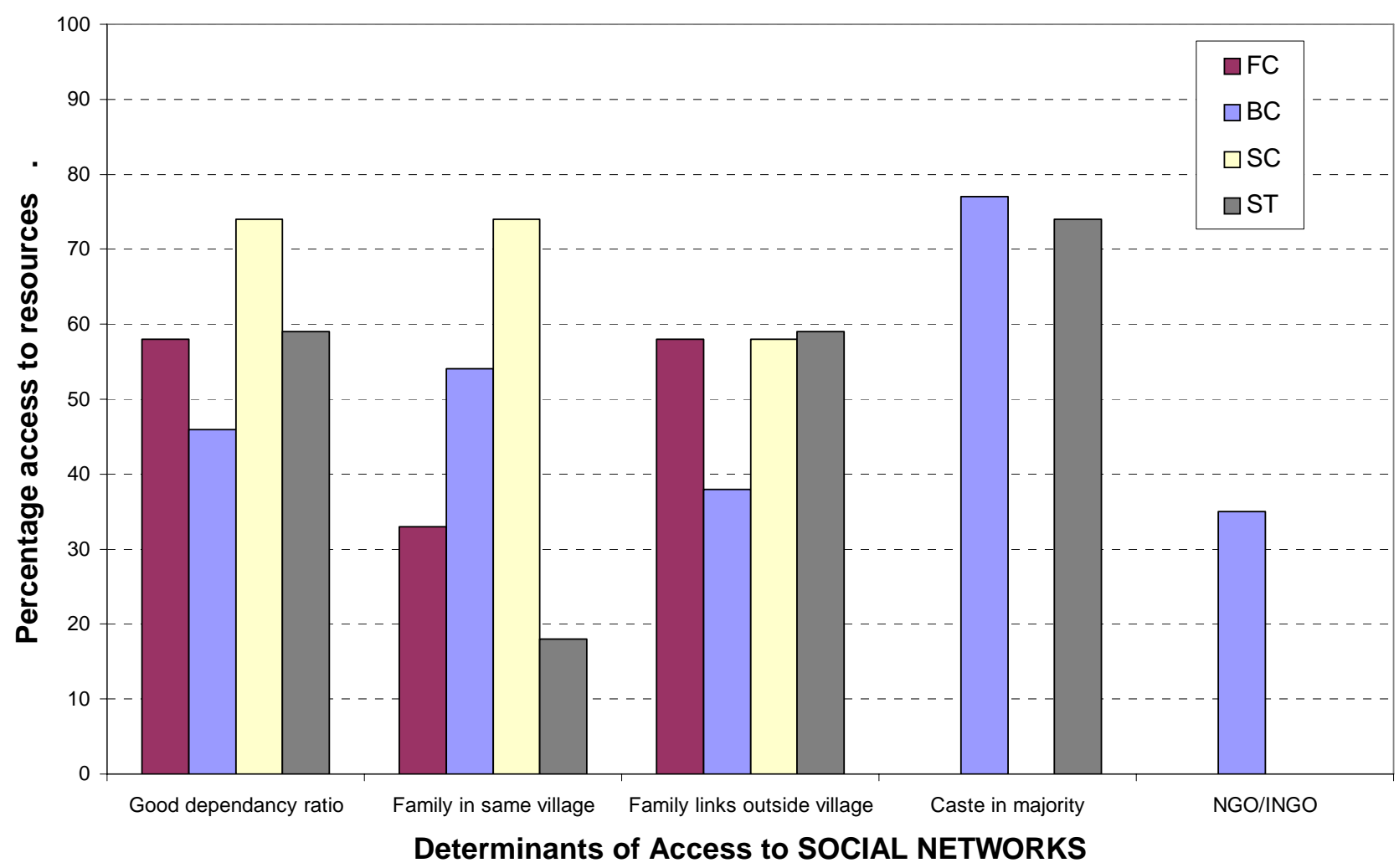


Figure 8:

Access to Political Networks by Gender

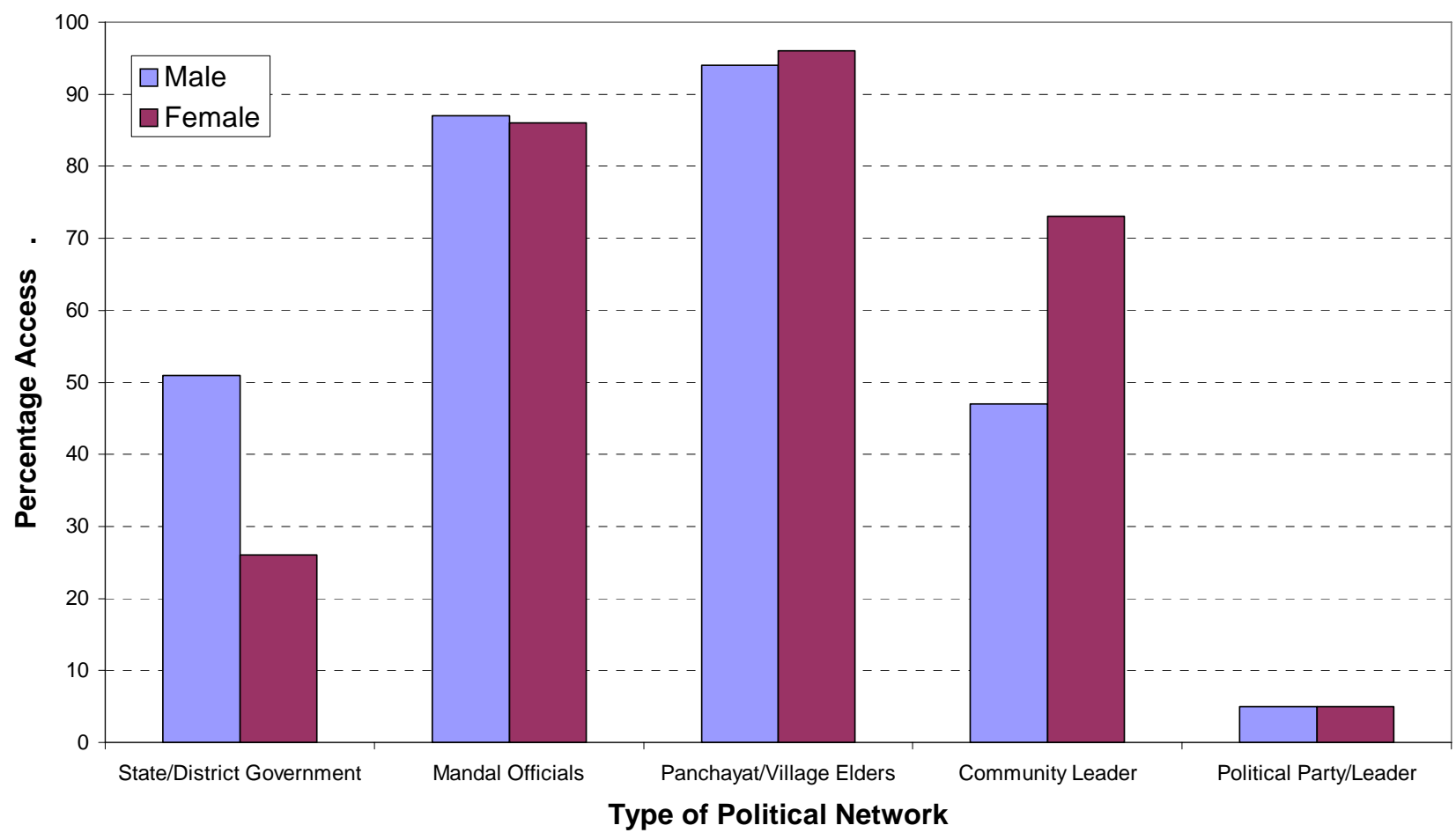


Figure 9:

Access to the four types of resources by educational attainment

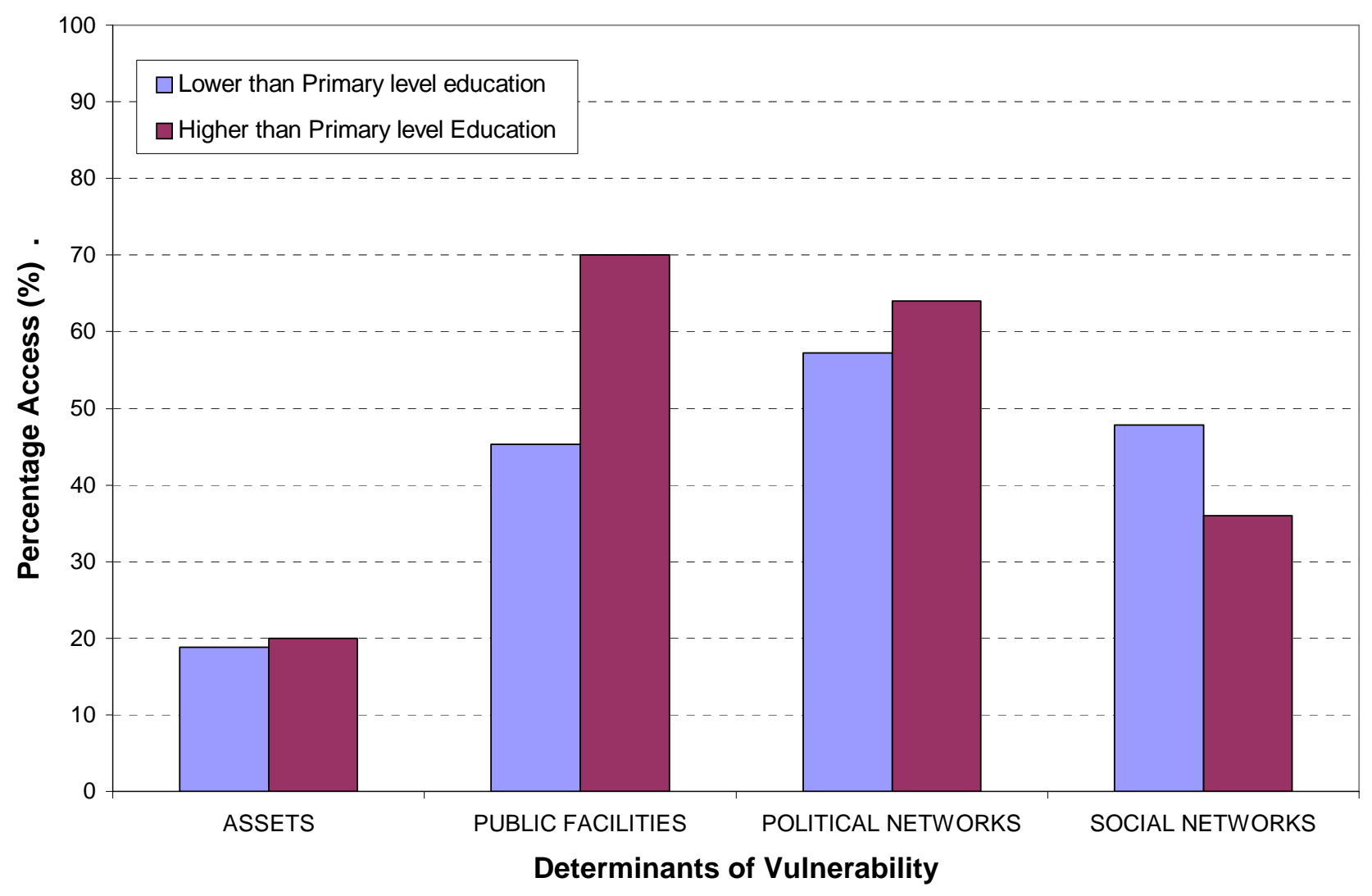


Table 1:

Four main socio-economic determinants of vulnerability and the variables that were used to assess them

\begin{tabular}{|c|c|c|}
\hline Determinant & Variables & \begin{tabular}{|l|} 
Data \\
sources
\end{tabular} \\
\hline $\begin{array}{l}\text { Access to } \\
\text { assets }\end{array}$ & $\begin{array}{l}\text { 1. Ownership of livestock } \\
\text { 2. Own or lease land } \\
\text { 3. Has savings/access to credit } \\
\text { 4. Ownership of income generating equipment (i.e. boat) } \\
\text { 5. Ownership of other assets (i.e. bicycle, scooter) }\end{array}$ & $\begin{array}{l}\mathrm{Q}, \mathrm{O} \\
\mathrm{Q}, \mathrm{S}, \mathrm{O} \\
\mathrm{Q}, \mathrm{I} \\
\mathrm{Q}, \mathrm{O} \\
\mathrm{Q}, \mathrm{O}\end{array}$ \\
\hline $\begin{array}{c}\text { Access to } \\
\text { public } \\
\text { facilities }\end{array}$ & $\begin{array}{l}\text { 6. Access to protected drinking water } \\
\text { 7. Access to (or own) a cyclone resistant house } \\
\text { 8. Access to a cyclone shelter } \\
\text { 9. Access to a Medical Centre within } 5 \mathrm{kms} \\
\text { 10. Higher than primary level education }\end{array}$ & $\begin{array}{l}\text { Q, S } \\
Q, S, O \\
Q, S, O \\
Q, S \\
Q, S\end{array}$ \\
\hline $\begin{array}{c}\text { Access to } \\
\text { political } \\
\text { networks }\end{array}$ & $\begin{array}{l}\text { 11. Networks with the State/District Government } \\
\text { 12. Networks with Mandal Officials } \\
\text { 13. Networks with the Panchayat/Village Elders } \\
\text { 14. Networks with a Community Leader } \\
\text { 15. Networks with a Political Party/Leader }\end{array}$ & $\begin{array}{l}\text { Soc., I } \\
\text { Soc., I } \\
\text { Soc., Q, I } \\
\text { Soc., I } \\
\text { Soc., Q, I }\end{array}$ \\
\hline $\begin{array}{c}\text { Access to } \\
\text { social } \\
\text { networks }\end{array}$ & $\begin{array}{l}\text { 16. Good worker/dependant ratio } \\
\text { 17. Family members in the same village } \\
\text { 18. Links with family members outside the village } \\
\text { 19. The respondent's caste in the majority within the village } \\
\text { 20. The respondent is actively involved with a NGO/INGO }\end{array}$ & $\begin{array}{l}\text { Q } \\
\text { Q, Soc. } \\
\text { Q, Soc. } \\
\text { Q, S, I } \\
\text { Q, S, I }\end{array}$ \\
\hline
\end{tabular}

Sources of data: Q-questionnaire survey; $\mathrm{S}=$ village mapping survey; $\mathrm{O}=$ field observations; I = semi-structured interviews; Soc. $=$ sociograms $($ Bosher 2005) 
Table 2:

Dominant characteristics of respondents in the lowest and highest Resource Accessibility Vulnerability Index quartiles

\begin{tabular}{|l|l|l|}
\hline Variable & \multicolumn{1}{|c|}{$\begin{array}{c}\text { Lowest quartile } \\
\text { (most vulnerable) [n=68] }\end{array}$} & $\begin{array}{c}\text { Highest quartile } \\
\text { (least vulnerable) [n=73] }\end{array}$ \\
\hline Gender & Male & Female \\
\hline Gender of head of household & Male & Female \\
\hline Caste & Mala (SC) & All FC castes \\
\hline Caste class & ST castes & FC castes \\
\hline Education level & No education attained & Up to tertiary level attained \\
\hline Mandal & Tallarevu (E. Godavari) & Thotapalligudur (Nellore) \\
\hline Village type & Village with no NGO & Village with long-term NGO \\
\hline Main occupation of village & Agriculture & Fishing \\
\hline Caste composition of village & Multi-caste & Single-caste \\
\hline Type of house & Basic wooden hut & Concrete house (large \& small types) \\
\hline
\end{tabular}

Note: The Chi Squared statistics for the cross tabulations that contributed to this table are all statistically significant at the 0.01 level 
Table 3:

The proportions of respondents in each quartile of the Resource Accessibility Vulnerability Index by caste classification

\begin{tabular}{|l|c|c|c|c|}
\hline & \multicolumn{4}{|c|}{ Caste Classification } \\
\hline Quartile & FC & BC & SC & ST \\
\hline Lowest quartile & $0 \%$ & $21 \%$ & $29 \%$ & $32 \%$ \\
\hline Low average quartile & $25 \%$ & $19 \%$ & $23 \%$ & $12 \%$ \\
\hline High average quartile & $25 \%$ & $32 \%$ & $38 \%$ & $56 \%$ \\
\hline Highest quartile & $50 \%$ & $28 \%$ & $10 \%$ & $0 \%$ \\
\hline
\end{tabular}

Table 4

The levels of education attained by caste classification

\begin{tabular}{|c|c|c|c|c|c|}
\hline & \multicolumn{4}{|c|}{ Caste classification } & \multirow[b]{2}{*}{ Average } \\
\hline Level of education & $\mathrm{FC}$ & $\mathrm{BC}$ & $\mathrm{SC}$ & ST & \\
\hline No education & $18 \%$ & $62 \%$ & $62 \%$ & $50 \%$ & $61 \%$ \\
\hline A 'few years' at primary level & $45 \%$ & $33 \%$ & $35 \%$ & $50 \%$ & $36 \%$ \\
\hline Completed primary only & $18 \%$ & $3 \%$ & $3 \%$ & $0 \%$ & $1 \%$ \\
\hline Secondary & $10 \%$ & $0 \%$ & $0 \%$ & $0 \%$ & $1 \%$ \\
\hline Tertiary & $9 \%$ & $2 \%$ & $0 \%$ & $0 \%$ & $1 \%$ \\
\hline
\end{tabular}

Statistics: $\chi^{2}=54.284 ;$ significant $\mathrm{p}<0.01$

Table 5:

Highest and lowest Resource Accessibility Vulnerability Index quartiles for different age categories

\begin{tabular}{|c|c|c|}
\hline & \multicolumn{2}{|c|}{$\begin{array}{c}\text { Percentage of respondents in the lowest and highest quartiles } \\
\text { of the Resource Accessibility Vulnerability Index }\end{array}$} \\
\hline Age Category & Lowest quartile & Highest quartile \\
\hline $20-30$ years old $(n=43)$ & $28 \%$ & $26 \%$ \\
\hline $30-40$ years old $(n=95)$ & $21 \%$ & $19 \%$ \\
\hline $40-50$ years old $(n=107)$ & $21 \%$ & $22 \%$ \\
\hline $50-60$ years old $(n=32)$ & $18 \%$ & $41 \%$ \\
\hline Over 60 years old $(n=28)$ & $29 \%$ & $14 \%$ \\
\hline Average $(n=305)$ & $22 \%$ & $23 \%$ \\
\hline
\end{tabular}

Statistics: $\chi^{2}=9.768 ; \mathrm{p}>0.05$ (not significant) 